Englishes in Practice 2015; 2(1): 1-38

DOI 10.1515/eip-2015-0001

\title{
Ali Karakaş
}

\section{Orientations towards English among English-medium Instruction Students}

\section{Abstract}

Based on the empirical data of my PhD research, this paper analyses the perceptions of 351 undergraduate students enrolled at English-medium universities towards English in terms of the language ideology framework. The students were purposively sampled from three programs at three Turkish universities. The data were drawn from student opinion surveys and semi-structured interviews. The findings paint a blurry picture, with a strong tendency among most students to view their English use as having the characteristics of dominant native varieties of English (American English \& British English), and with a high percentage of students' acceptance of the distinctiveness of their English without referring to any standard variety. The findings also show that many students' orientations to English are formed by two dominant language ideologies: standard English ideology and native speaker English ideology. It was also found that a large number of students did not strictly stick to either of these ideologies, particularly in their orientation to spoken English, due, as argued in the main body, to their experiences on language use that have made them aware of the demographics of diverse English users and of the diverse ways of using English.

Keywords: English-medium, language policy, language ideologies, standard English 


\section{Öz}

Bu çalışma doktora araştırma verilerime dayanarak 351 lisans öğrencisinin İngilizceye karşı algılarını dil ideolojisi kuramsal çerçevesi açısından analiz etmektedir.

Öğrenciler, amaçı örneklem yoluyla öğretim dili olarak İngilizceyi kullanan üç Türk üniversitesinin üç farklı bölümünden örneklenmiştir. Araştırmanın verileri, ağırlıkı olarak öğrenci görüşü anketleri ve yarı-yapılandırılmış görüşmelerden elde edilmiştir. Bulgular, öğrenciler arasında kendi İngilizcelerinin baskın İngilizce çeşitlerinin (Amerikan İngilizcesi ve Britanya İngilizcesi) özelliklerine sahip olduğunu düşünme eğilimi ve öğrencilerin büyük bir oranının herhangi bir standart İngilizce türünü ima etmeden kendi İngilizcelerinin farklıı̆ını kabul etmeleri açısından bulanık bir tablo sunmaktadır. Analizler, aynı zamanda birçok öğrencinin İngilizceye yönelimlerinin 'standart İngilizce' ideolojisi ve 'anadili İngilizce olan kişi' ideolojisi olmak üzere iki baskın dil ideolojisi tarafından şekillendirildiğini göstermektedir. Diğer taraftan, öğrencilerin önemli bir kısmı, farkı İngilizce kullanıcılarının demografik özellikleri ve çeşitli İngilizce kullanım şekillerinden kendilerinin haberdar olmalarını sağlayan dil kullanımı deneyimleri sayesinde her iki ideolojiye de tam anlamıyla bağlıık göstermemiştir.

Anahtar kelimeler: Eğitim dili olarak İngilizce, dil politikası, dil ideolojileri, standart İngilizce

Ali Karakaş: University of Southampton, UK. Email: ak16g11@soton.ac.uk

\section{Introduction}

Much has changed in higher education across the world mostly because of the impacts of globalization and internationalization processes leading to a borderless network among human beings. One single example of many changes is concerned with language, more specifically the language used in teaching tertiary level courses. Recent reports and research identified the dramatic increase in the number of English-medium programs, particularly in relation to European and several other countries where English is spoken neither as the first nor official language (e.g. Dearden, 2014; Wächter \& Maiworm, 2008). As might be expected, Turkish universities are no exception in this current fashion towards using English as the 
medium of instruction (EMI). Moreover, Turkish higher education, according to OECD reports $(2011,2013)$, is becoming more and more international by nature as a direct corollary of its universities' international student cohorts, and academic staff profiles to a lesser extent. A transformation of this sort occurring in EMI universities means that English will be used more widely as a lingua franca, i.e. "a vehicular language spoken by people who do not share a native language" (Mauranen, 2003, p. 513) rather than a foreign language as it was two or three decades ago.

The shift from English being taught as a foreign language to English being used as a lingua franca has potentially far-reaching implications. A simple case in point is related to the way speakers of English, particularly non-natives, are conceptualized. Will they still be labelled as 'failed learners' with deficit English skills? Or, will they get their own share from this recent change in the use of English? In this regard, there is an emerging consensus that those who draw on English for academic studies should not be construed as learners any more, but 'users' (e.g. Ljosland, 2011; Pilkinton-Pihko, 2010) since English merely serves as a tool for them in the delivery and acquisition of subject area knowledge. Another point relates to the profile of users, e.g. who is going to use it, and with who, and where. The last point grapples with the question of how English will be used, i.e. whether it will be used in stark conformity with native English norms as has been largely the case, or in nonnormative manners varying from what is so-called standard English.

One critical issue regarding the aforesaid implications is, however, that although the strong trend towards EMI in universities has resulted in a wide range of related research such as cognitive-pedagogical aspects (e.g. Aguliar \& Rodriguez, 2012; Byun et al., 2010), socio-political and cultural aspects (e.g. Ljosland, 2010) and educational language planning aspects (e.g. Preisler, 2009), the linguistic aspect still remains under-researched. As put by Turner and Robson (2008), the linguistic aspect concerns language policy and practice matters of tertiary institutions. The concept of language policies can, at this juncture, be conceived as "specific documents, laws, regulations, or policy documents" that specify the issues around language use in a particular domain (Shohamy, 2006, p. 45). Spolsky (2004) puts forward that language policy research can be undertaken focusing on the three 
dimensions of language policy, i.e. how language is used (language practice), beliefs about how it should be used (language beliefs) and attempts of modifying the use of language by leading users to adopt certain manners of language use (language management). Within this multi-componential model, this paper will particularly make use of the beliefs and the language management dimensions while attempting to determine the participants' orientations. The language practices will be scrutinized meta-linguistically by asking the students what they feel about their language use rather than a direct observation of their language behaviours.

Another argument posits that the study of language policies has close ties with the concept of language ideologies. For instance, to Spolsky (2004, p. 14), "language ideology is language policy with the manager left out, what people think should be done" while using the language. As a well-critiqued term, there are different views on the concept of language ideology (e.g. Lippi-Green, 2012; Makihara \& Schieffelin, 2007; Milroy \& Milroy, 2012). Although many scholars, both inside and outside the field of linguistics, neutrally view ideology as a set of beliefs/ideas, there are also others who state that ideology is power-laden, and serves as a tool in the hands of power holders to enforce their views about language and its speakers: how it should be used, taught and learned. I will take the term language ideology as a concept that is enforced by the dominant groups to promote their own interests and needs over those of the less powerful groups, and in the context of my research discussions around 'standard English' and 'native English speaker' are salient. These ideologies, imposed by power holders through various tools, have a close link to the prescriptivist school of thought in which language use is measured against grammatical correctness and competence of native-speakers, who are assumed to be expert users of the language, and thus the ideal model for speakers of English (Doerr, 2009; Pennycook, 1994).

It is further averred that there are several dynamics that have a place in regulating people's thoughts, and more importantly their linguistic behaviours, such as testing, teaching materials (e.g. dictionaries, usage books, handbooks on language), and policy actors, e.g. teachers (Milroy, 2001; Shohamy, 2006). As Shohamy (2006) firmly puts it, "all mechanisms are forms of marketing language ideologies" to 
language users (p. 57). With respect to such mechanisms, Brown (2010) calls specific attention to the role of language teachers as key policy actors who can "reproduce and challenge existing language ideologies in the school environment" (p. 298). The same role can be likely taken over by lecturers, too, in higher education institutions. Therefore, their expectations from students with respect to English language use merit closer investigation. This is an aspect which will be explored by referring to what the students have to say in relation to their lecturers' expectations on language use. Moreover, previous language learning experiences largely constructed by language teachers and the aforesaid materials may also shape their orientation to English, for the students have had a long history of language learning and many of them were trained in the language support programs (e.g. preparatory schools) of their universities before they were placed in their degree programs. Therefore, the potential impacts of such dynamics will be also considered.

In the area of ELT research, many scholars have looked at students' and language teachers' orientations to English through attitudinal and opinion research. In a number of studies, it was seen that ELT professionals and learners of English from a wide range of contexts favoured native English models, predominantly American English, with positive attitudes while they displayed less positive attitudes to their own English and non-native Englishes, particularly accents (e.g. Bayard et al., 2001; Jenkins, 2007; Ladegaard \& Sachdev 2006). Moreover, the feeling of ownership seemed not too strong among non-native English learners even if English was deemed as an international language at the practical level (e.g. Matsuda, 2003).

Research into the attitudes of professionals who use English for business purposes has revealed beliefs about English that are similar to those found in the field of ELT. For example, A.W. Lee (2012) found the idea of ownership by its native speakers among Taiwanese people in the service sector, with a strong adherence to nativelike pronunciation. Likewise, multinational business professionals were found to harbour pejorative attitudes to their colleagues' non-standard English, using such descriptors as 'uneducated accents' and 'non-articulated English' when describing their English (Rogerson-Revell, 2007), despite their application of some 
communication strategies (e.g. accommodation, modification) to have a smooth interaction. Other research, however, showed the embrace of a pragmatic approach by business people to the use of English, prioritizing effective communication over linguistic correctness (e.g. Ehrenreich, 2010; Kankaanranta \& Louhiala-Salminen, 2010). As distinct from ELT people, the non-ELT professionals seemed to attach more importance to doing the job through English without being worried much about the correctness of linguistic forms despite their negative judgments on nonstandard accents and pronunciations. These findings share similarities with those conducted in higher education, as discussed in the next paragraph.

Among the relatively few studies carried out on linguistic aspects of higher education, researchers have addressed rather significant matters, with striking findings which call for further research in respect of EMI. For example, PilkintonPihko (2010) explored engineering lecturers' perceptions of their language use in an EMI context, and found that their main concern was lecturing rather than native speakerism. In other words, the capability of teaching and communicating through English was of vital importance for them while the correctness of linguistic forms played secondary role to communicative effectiveness. Thus, they were not stringently subscribed to standard language ideology or native English ideology, but their beliefs were different to some extent subject to what they targeted as effective. Similarly, it was discovered by Björkman (2008) that non-English major lecturers and students in a Swedish technical university focused more on function rather than the standard forms when using English. This finding was in line with what Erling (2007) discovered with German EMI students who conceptualized the notion of 'good English' not against a native speaker model, but in terms of the effective use of English in diverse English speaking sites. In stark contrast, however, a study with Turkish academics showed that they sought a close affinity to American English while defining the English they used, with an aspiration to write as American speakers do (Karakaş, 2014).

Turning to studies on language policy, Jenkins' (2014) research on language policies of so-called international universities showed that the universities enforced certain kinds of native English norms on students and academic staff, and that many 
academic staff recruited in the study from a wide array of countries were strictly normative in terms of their expectations from students concerning language use, particularly in written English. Likewise, Saarinen and Nikula (2013) observed that a Finnish university demanded native English proficiency from its prospective students to be able to commence their degree programs by means of their English entry tests, e.g. TOEFL and IELTS. In the Danish context, Kuteeva (2014) reported that a considerable number of students set unachievable goals for themselves as regards English language proficiency in academic events, taking conformity to the standard native English norms as a yardstick in their statements.

Although these findings are significant, the research in Turkey is presently at an embryonic stage as for EMI from a language policy perspective. Therefore, for this paper, the focus shifts to orientations of Turkish university students to English, more precisely, towards spoken and written English. Answers will be sought to the following research questions:

1. How are Turkish university students oriented towards their English and English use when it serves as a vehicle for academic studies?

2. What language ideologies are prevalent among students' orientation to English and what factors are involved in the formation of these ideologies?

\section{Methodology}

\subsection{Participants}

351 undergraduate students from three top-tier universities (i.e. Bogazici University, $\mathrm{N}=106$; Bilkent University, $\mathrm{N}=132$; and Middle East Technical University, $\mathrm{N}=113$ ) of Turkey took part in the questionnaire part of the study, 20 of whom were later interviewed. As to their demographic characteristics, 179 were male and 172 were female. Their age range varied between 18 and 24 in general. The participation in the study was on a voluntary basis and students were granted the right to withdraw any time during the survey. They had all been studying English for at least 12 years as a school subject before they started university, and at the time of starting their degree programs, their English proficiency had been certified as intermediate or 
above $^{\underline{1}}$. The students were sampled from the following disciplines: international relations ( $\mathrm{N}=106)$, mechanical engineering (138) and history ( $\mathrm{N}=107)$. All students had at least two years of experience of being in English-medium education at the time of data collection depending on which year they were in.

\subsection{Data collection and analysis}

Data were elicited from 351 students through survey questionnaires with closedended statements, and later through one-to-one semi-structured interviews with 20 of these respondents, who were invited to discuss their questionnaire answers in depth. Only the relevant questions to this study are reported from the original questionnaire (see Appendix A for the questions). For the questionnaire study, paper-and-pencil questionnaires were distributed to those students who agreed to take part, in their class hours with the permission of course lecturers. The language of the questionnaires was English.

The students who agreed to take part in the in the interview study wrote down their email addresses on their questionnaire forms. Although I contacted about 30 voluntary students via emails, only 20 students took part in the interviews held in various locations and the rest preferred to sit out for various reasons. Some students were interviewed on Skype in accordance with their own request as they were far away from their university for a range of reasons like being abroad for an exchange program, visiting their parents before the mid-term exams, etc. The participants opted for Turkish, their mother tongue, as the language of interviews. Thus, the data presented in the findings section were translated from Turkish to English and crosschecked by a Turkish PhD student of applied linguistics.

Quantitative data analysis was carried out using SPSS 21. To investigate students' perceptions of their own English and what goals they set for themselves in the productive skills of English (i.e. spoken and written), descriptive tests, including percentages and frequencies, were conducted. The purpose was to see the general trend and patterns in the distributions of their responses to the questions.

${ }^{1}$ Students can certify their lanquage proficiency either by taking international proficiency tests (e.q. TOEFL, IELTS, etc) or by taking insitutionally administered language proficiency tests. 
Using Nvivo 10, the qualitative data were analysed by a combination of qualitative content analysis (Schreier 2012) and discourse analysis, following Dörnyei's (2003) four phases in qualitative data analysis. Firstly, I transcribed all recordings and turned verbal data into textual data (see Appendix B for the interviewee profiles and Appendix C for the transcription conventions). Subsequently, I did initial coding to get familiar with the data and issues discussed. This was ensued by the main coding, the prime objective of which was to develop themes based on the identified codes. The process of coding included a combination of concept driven and data driven coding through which I was able to relate the codes to the topics discussed in the questionnaire, and was able to analyse what was there in the data. In the following sections, the findings relative to the theme 'concerns about language use' (written and spoken) will be presented.

\section{Findings}

\subsection{Findings from quantitative data}

Questionnaire results are presented around the two main topics: (1) students' description of their perceived English and (2) students' goals in written and spoken academic English.

\subsubsection{Students' perceptions of own English}

Whilst attempting to determine students' orientations to English, it is imperative to discover the way they perceive the English they have and use. Through looking at their perceived English use, we can understand whether students see their English as having (or not having) the characteristics of a standard variety of English. Besides, it becomes possible to see whether they acknowledge their English with its own characteristics (i.e. their idiolect) being influenced by some other standards and by their own native language (i.e. Turkish). Based on earlier research (see Guerra, 2005), they were given 4 options (see fig. 1 below) in the format of a multiple choice to choose the one that best describes their English.

By means of descriptive analysis, as shown in Figure 1 below, it was found that around half of the students (47.9\%) associated their English with American English 
whilst only a small percentage (8.5\%) stated that the English they use is closer to British English. Although this high number affiliated their English with a native kind of English, more than $40 \%$ characterized their English with the traits of the Turkish language.

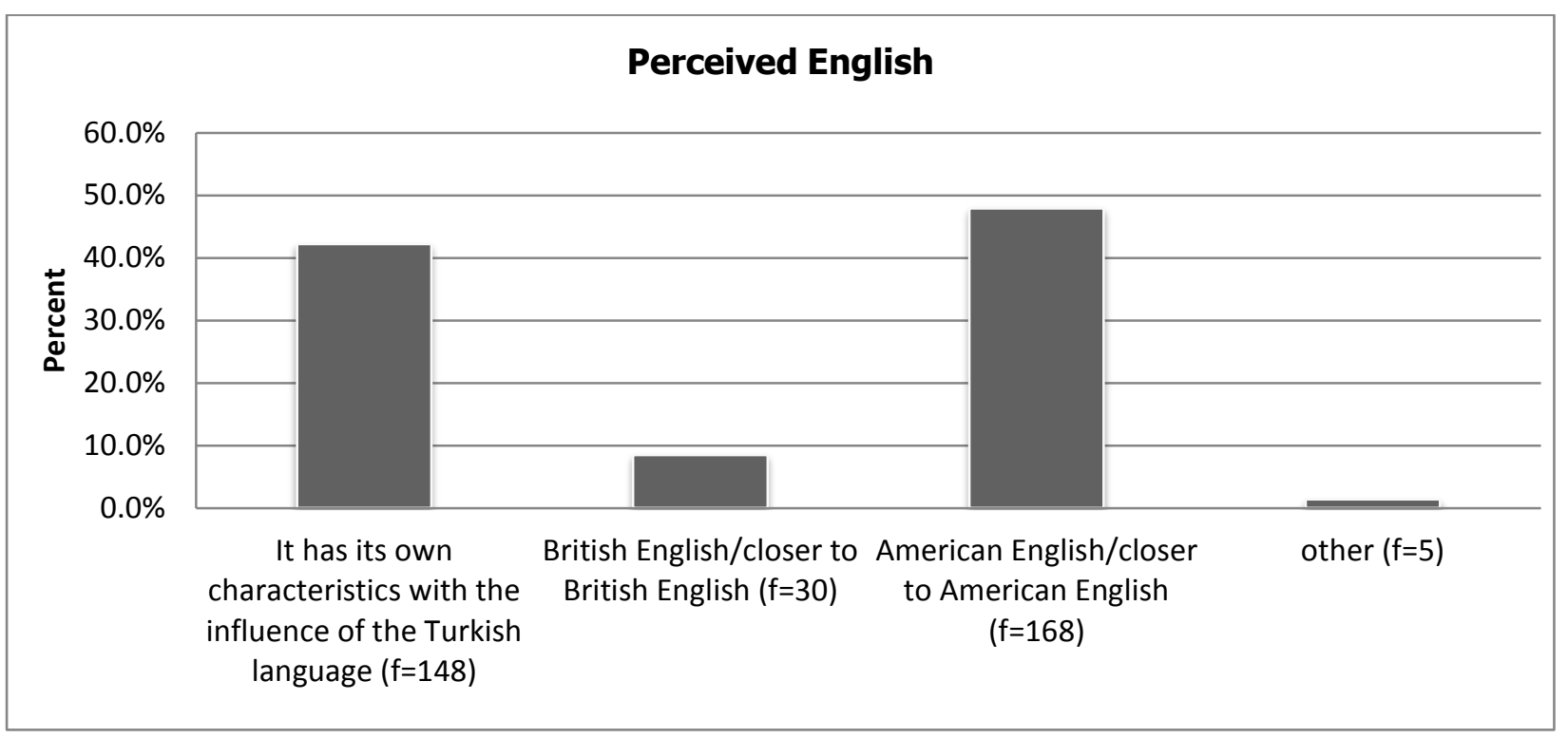

Figure 1. Students' perceptions of their own English

Students were also given the choice to give a different answer from the given options in the questionnaire. Only five students (1.4\%) provided different answers to the question of how they perceive the English they use. Two of them referred to the fact that their English is 'British + American mix' and 'mixed'. The other two put it more precisely, one stating that "It has (its) own characteristics and also is closer to British Eng. in writing", and the other claiming that "I do not have such a concern as long as I am understood".

\subsubsection{Students' goals in written and spoken academic English}

The exploration of students' goals is a crucial point to be able to make out their orientations to English, as their goals may suggest whether they prioritize the concept of 'native speaker competency' by aiming at native speaker models or they underscore the significance of being 'a competent user' who can manage successful communication without being bothered by the conventional rules of native English in their written and verbal interactions. To this end, students were given five goal 
statements to choose so that they can opt for the option that best describes their goals.

\section{Goals in written academic English}

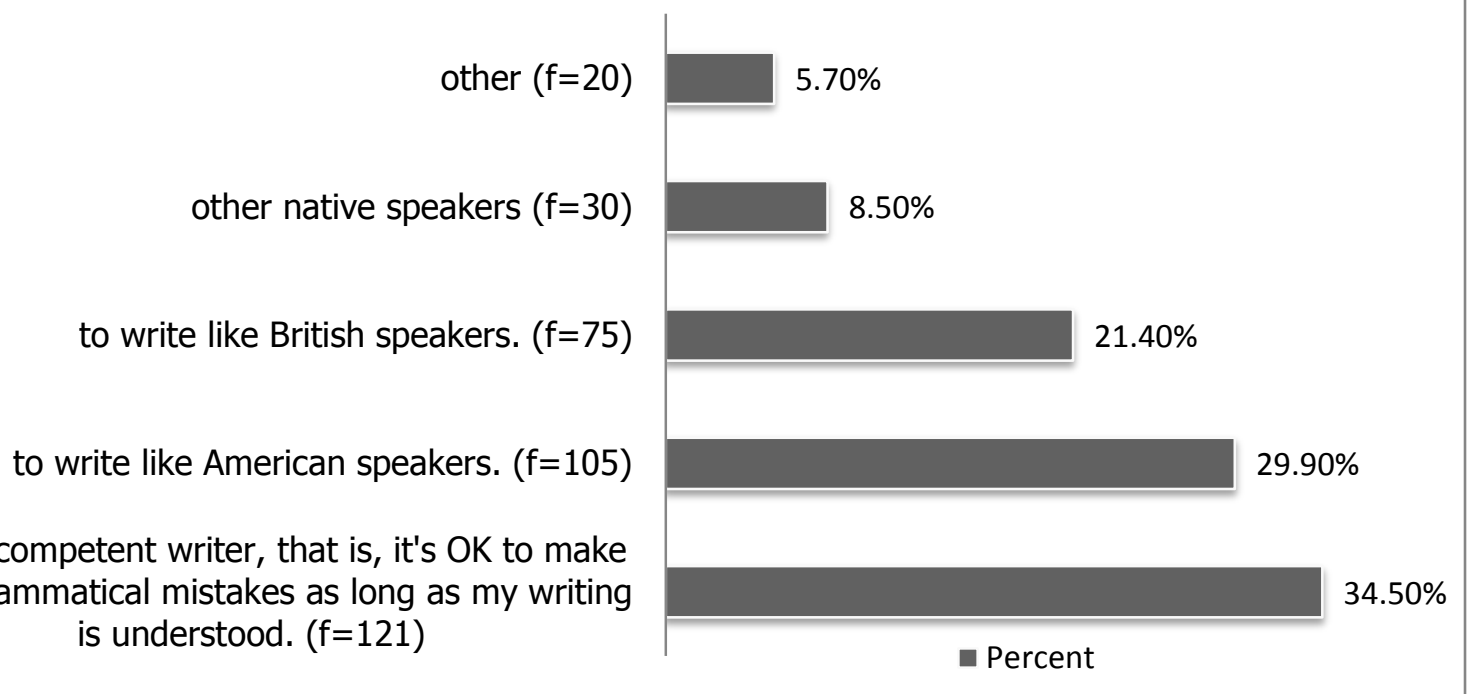

Figure 2. Students' goals in written academic English

According to the results (Fig. 2), more than one third (34.5\%) reported their goal to be a competent writer who can tolerate grammatical mistakes on condition that their writing remains comprehensible to the reader. Yet, slightly more than half of the students $(59.8 \%)$ were geared towards having a native speaker writing competency. The results seem to reveal a hierarchical order among the types of native speaker competency they aim for, with the majority targeting at American speakers' writing competency (29.9\%) and British speakers' writing competency (21.4\%).

It was seen that a small percentage (5.7\%) wrote down their goals in their own words by going for the 'other' option. As Table 1 summarized below, many students expressed their objective to be a 'competent writer' who can clearly, beautifully and correctly communicate their ideas without making any grammatical mistakes (S81; S149; S229; S247; S257; S268; S320). Of those seeking to be competent writers in their own ways, some indicated that they could tolerate a small number of mistakes (S43) and only the simple or basic grammatical mistakes in their writing (S346). 
Moreover, it was further remarked by some students that they did not intend to have a native speaker model for written English by giving the reason that there is no privilege enjoyed by native speakers in academic writing (S149; S268) and their own writing is already sufficient enough, and had no intention of emulating native speakers (S71). There was only one case in which a student exhibited a strong adherence to having a native speaker writing competency, without referring to a particular model (S344).

Table 1. The summary goals of students choosing the 'other' option in academic writing

\begin{tabular}{|c|c|}
\hline Student ID & Goals \\
\hline S43 Bogazici IR & to write the best way I can with only some mistakes \\
\hline S71 METU H & $\begin{array}{l}\text { I have excellent writing skills so I dont want to be like natives. I } \\
\text { am more than them }\end{array}$ \\
\hline S81 METU ME & to express my ideas correctly \\
\hline S149 Bilkent H & $\begin{array}{l}\text { it's not ok to make some grammatical mistakes but other than } \\
\text { that, I don't need to write LIKE somebody else }\end{array}$ \\
\hline S229 Bilkent H & $\begin{array}{l}\text { I believe that except bilinguals, it's really hard to write like a } \\
\text { native speaker. Of course it's possible to improve it a lot, but } \\
\text { my goal is not writing like a native speaker. It's OK for me to } \\
\text { write without grammatical mistakes while I'm improving my } \\
\text { writing in terms of the way it is expressed by the natives (the } \\
\text { way language is used can be improved a lot, but difficult to } \\
\text { capture a native's expressions in a short time }\end{array}$ \\
\hline S247 Bogazici H & to write without any grammatical error \\
\hline S257 Bogazici IR & $\begin{array}{l}\text { When It comes to writing, i don't mind whether it's British or } \\
\text { American but I mind how beautiful and grammatically correct it } \\
\text { is. }\end{array}$ \\
\hline S268 Bilkent IR & $\begin{array}{l}\text { It's a good writing as long as there is a big range of vocabulary } \\
\text { and good grammar. You do not have much advantage if you } \\
\text { are native when it comes to writing. }\end{array}$ \\
\hline S320 Bogazici ME & $\begin{array}{l}\text { It does not matter as long as I avoid mistakes and state my } \\
\text { ideas clearly. }\end{array}$ \\
\hline S344 Bogazici IR & to write like any native English speaker \\
\hline S346 Bogazici ME & $\begin{array}{l}\text { I don't need to write like Native speakers. However, my writings } \\
\text { should be simple, haven't any simple grammatical mistakes, } \\
\text { and to read and understand them should be easy. }\end{array}$ \\
\hline
\end{tabular}


Students' goals in spoken academic English were explored through similar questions as those for written English. As for the students' goals for spoken English, descriptive test results pointed out that over half of the students $(51.8 \%)$ set their goal as to get closer to the competence of a native speaker while speaking English. In a hierarchical order, many (33.9\%) desired to speak like American speakers while $13.1 \%$ reported that they wanted their speaking to be like that of British speakers. The least interest (4.8\%) was expressed in favour of having the speaking competence of other native speakers. Notwithstanding the high number of students aiming for native speaker competence, a large number of students (45.3\%) paid attention to communicative efficiency in their avowed goals, with a special emphasis on the fact that effective spoken communication is more important than avoiding mistakes and sounding like native speakers. Figure 3 presents students' responses on their goals for speaking English in frequencies and percentages.

\section{Goals in spoken academic English}

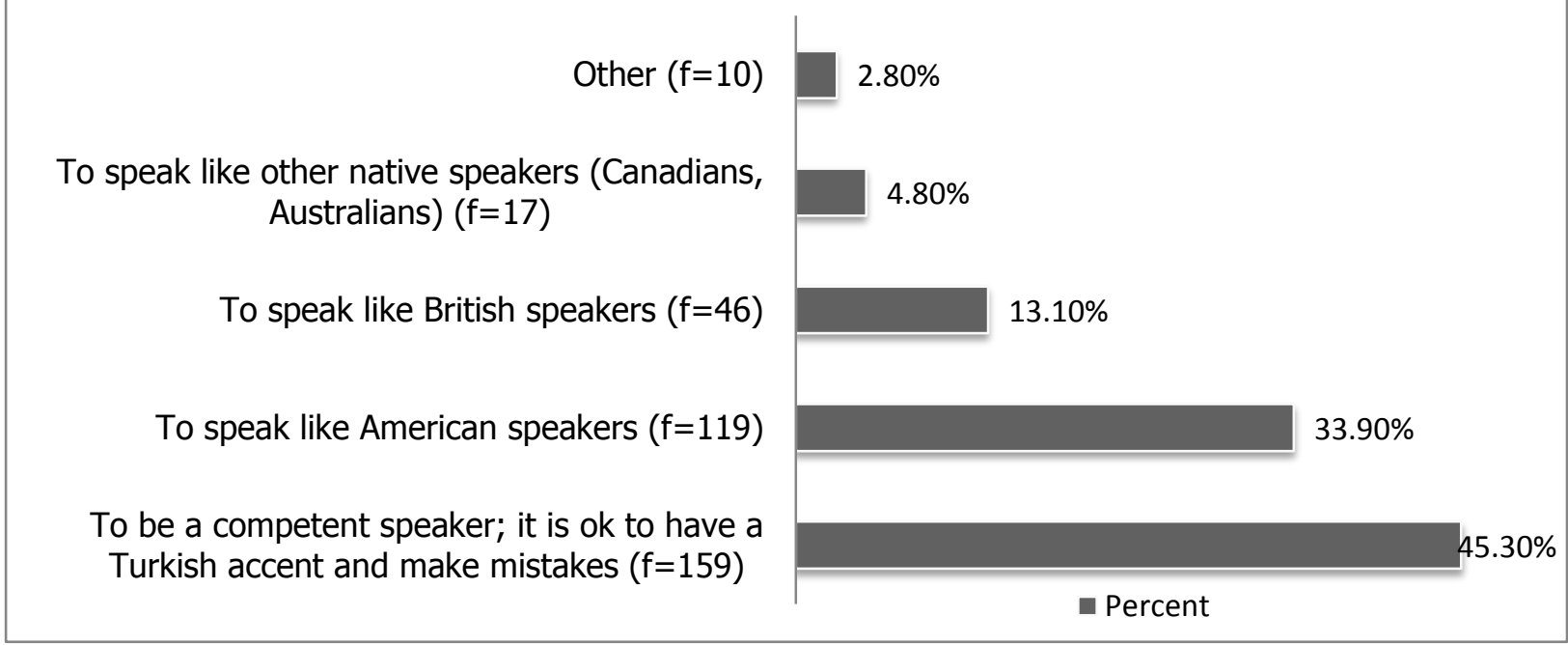

Figure 3. Students' goals in spoken academic English

However, a small minority (2.8\%) chose the 'other' option and accounted their goals in speaking in their own words. Several underlined the fact that although they aspired to be a competent speaker who does not mind retaining his/her own accent, they considered making mistakes unacceptable within this goal (S185; S283). Some defined their goals from the point of acquiring 'fluency' to a degree in which they can easily express themselves (S221; S43) and make themselves understood by a 
larger group people who both speak English as first (native speakers) and additional or second language (non-native speakers) (S63; S320). Only one student (S158) referred to a native speaker model (Irish English) which is the kind of English spoken where the student will sojourn as an exchange student.

Table 2. The summary goals of students choosing the 'other' option in academic speaking

\begin{tabular}{|c|c|}
\hline Student ID & Goals \\
\hline S43 Bogazici IR & to speak fluently so that I can explain myself \\
\hline S63 METU IR & [to] communicate people \\
\hline S158 Bilkent ME & $\begin{array}{l}\text { to speak like an Irish, I'm about to go to Ireland for exchange } \\
\text { program }\end{array}$ \\
\hline S185 Bogazici H & $\begin{array}{l}\text { to be a competent speaker, that is, it's OK to have a Turkish } \\
\text { accent as long as there is no grammatical mistakes }\end{array}$ \\
\hline S221 Bilkent H & To be a fluent speaker \\
\hline S283 Bogazici H & i can have accent but i should not do grammatical mistakes \\
\hline S320 Bogazici ME & $\begin{array}{l}\text { to speak fluently and to be understood not only by native } \\
\text { speakers but also the foreigners }\end{array}$ \\
\hline
\end{tabular}

On the whole, a closer inspection on students' choices for goals in spoken and written English provides evidence for the popularity of native speaker competence, particularly that of American speakers given that the number of students who set their goals in favour of a native speaker competence outnumber the number of students that give precedence to becoming successful communicators both in speaking and writing. Nevertheless, strikingly, students' tendency to target nativelike competence in writing seemed to be stronger than their orientation to native-like competence in speaking.

\subsection{Findings from qualitative data}

The quantitative data show how students perceived the English they use and what kinds of goals they set out for their written and spoken English. Through qualitative data analysis, it is aimed to ascertain students' expectations with regards to their English language use, written and spoken English in particular, and the potential factors that influence their expectations and guide their linguistic behaviours. Strictly speaking, it also seeks to unravel the language ideologies that surround and shape the way English is used by students as a means of academic study. In accordance 
with this purpose, I will look at the specific category of the students' concerns about English language use with reference to written and spoken English. To this end, students' perspectives, taken out of their interview data will be presented in the following sections.

\subsubsection{Perspectives on written English}

The data analysis disclosed that many a student was found to adopt rather conformist perspectives on their written English whereas there were a small number of students who had non-conformist perspectives to their written English. Initially, the results relating to the students' normative approach to written English will be given. Such students generally expressed their wish to follow traditional standards, i.e. standard written English while writing for academic purposes by adhering to standard grammar and certain stylistic rules of native academic English. Below is an example conversation exchange between me and an engineering student:

\section{Example 1: Conformist approach to written English}

1. S11: $\mathrm{i}$ exert considerable effort while writing essays or assignments (.) $\mathrm{i}$

2. use the dictionary a lot even to look up the words that I have already known

3. (.) my biggest trouble is to find the most appropriate word to express a

4. notion in relation to my assignment (.) i spend a lot of time for this (2) i can

5. say i am good <at writing > i do not make basic mistakes in general (.)

6. particularly it is unproblematic in terms of grammar

7. A: you pay attention to writing correctly then? =

8. S11: = yes ABSOLUTELY

9. A: what is the reason for your tendency to make mistakes. sorry your 10. avoidance of making mistakes in writing (.) is it because of your lecturers' 11. reactions or are there other reasons?

12.S11: @ i'm a perfectionist person in general i am displeased with it (.) i pay 13. attention to doing my best in everything I do @@ lecturers can be very harsh 14. as regards corrections (.) i do not want to get back my assignment filled with 15.comments and corrections (.) OF COURSE marking plays a significant role in my 
16.attention <to correction> @@@ as i study through English-medium

17.instruction $i$ think $i$ show disrespect to myself if my writing is full of mistakes 18.(.) it is like disrespect to my efforts

The above conversation took place after I asked S11 what she thought about her written English. Her lengthy comment (II. 1-6) demonstrates that she is seriously concerned about academic writing, particularly about finding 'the most appropriate word to express a notion' in her papers. Here, her concern with 'appropriacy' of word choice is clearly apparent. In addition, her description of herself as being 'good' at writing, and her successive statement that she does 'not make basic mistakes in general' (I.5), particularly in grammar, shows how she links the notion of 'good writing' to notion of (grammatical) correctness. When asked a suggestive question whether it really matters for her to write correctly (I.7), she latched my question in the affirmative, with added intensity on the factive adverb 'ABSOLUTELY'. Her emphasis on the adverb presents a presupposition of writing correctly as an accepted reality for her because she seems to be subscribed to the standard English ideology. Yet, the loaded words I used such as 'correctly' are also likely to have affected her answers.

While explaining why she is so concerned about correctness, S11 firstly associates her focus on correctness to her personality trait, i.e. 'a perfectionist person' who seeks to be the best in whatever she does (II. 11-12). Her ideologically loaded words ('correction', 'perfectionist' and 'best') suggest that writing correctly equals to doing her best in academic writing. Additionally, she implies that lecturers' correction made on papers and the possibility of penalty to students in marking leads S11 to use standard English (correct English) for fear of getting lower scores in case of failure to comply with the conventions of standard English grammar (II.13-16). At this point, we see how lecturers' expectations on language use can affect the students' perceptions of achievement, and enable them to adopt certain ways of language use.

What is more striking is that $\mathrm{S} 11$ develops a link between making mistakes and losing respect (II.17-18). She construes herself as different from others who do not study in EMI, thus regards making mistakes firstly as 'disrespect' to herself and 
secondly to her 'efforts'. The reason is probably because making mistakes is at odds with her 'perfectionist' character and her investment in conforming to grammatical standards. In short, S11 has a rather normative approach to written English, and negative attitude to non-standard language use, in other words, subscribing to the standard English ideology.

As with S11, there were other students who also strongly underlined the significance of grammatical correctness in writing. For example, an engineering student remarked that "when the wrong prepositions are used in a sentence, there might be changes in the intended meaning" (S2). Likewise, an international relations student stated that "it is absolutely important [to write correctly] especially if an academic text needs to be written such as an exam or a coursework" (S16). A history student, differentiating written English from spoken English, drew attention to the availability of time for writing and how this leads her to "correctness in anything" she writes (S18). More interestingly, it was noted by an engineering student who believes that "making grammar mistakes would constitute a problem in ethical terms", suggesting that "students' writing should be proofread by native speakers because if a native speaker understands the text. A non-native person can much easily understand it" (S19). Finally, another engineering student strongly stressed that he pays more attention to the correct usage of tenses and grammatical rules, purporting the view that "correcting mistakes and writing without mistakes is important for the readers to easily understand the content of the written text" (S20). However, it is unclear whether the student has this perception as a result of his previous experience or because of his beliefs about what effective communication should look like.

On the other hand, some students referred to some of their lecturers and their expectations of students to write in accordance with the norms of Standard English as much as they could. For instance, S16 made reference to some of his friends whose marks in their exams and written assignments were reduced owing to writing mistakes, particularly grammatical, being similar to what S11 implies above. Along similar lines, S18 explicated why she cares so much about correctness by pointing out that "as assignments are written English, lecturers are attentive to the language use as much as to the content of the assignments". S8 gave a more detailed account 
why they had to be wary of grammatical correctness. As he put, "even if not all, many lecturers lower students' grades more or less, though". He also acknowledges such lecturers to be right in their practices, concluding that "in order for thoughts to be able to be better understood [by interlocutors], grammar is supposed to be good at least to some extent".

In comparison to the high number of students who displayed normative orientation to written English, there were only a few students whose perspectives might be classified as non-conformist for the reason that they refused to conform to commonly established ideas of how 'good writing' should be by creating their own norms. To take the most obvious example, one student defined her expectation regarding her writing as "to be intelligible and to be able to convey what she wants to in writing" (S10). As she further adds, for her, what has the precedence in writing is not the correct usage of grammar, but "to write more properly in terms of content and structure and to present [her] arguments more coherently". Identically, S19 articulated his objective as "to be understood by a wider audience who can easily read and understand his writings without any confusion".

\subsubsection{Perspectives on spoken English}

Similar to the classification of perspectives on written English, students' perspectives about spoken English were put into two categories: conformist perspectives and non-conformist perspectives. As distinct from the findings about written English, students were found to be largely non-conformist when it comes to their expectations about spoken English. The findings that show students' non-normative approach to spoken English will be presented first. Example 2 below presents an instance of non-normative orientation to spoken English and unfavourable attitudes towards non-native speakers' mimicking native English accents, with an expressed concern on achieving a successful communication.

Example 2: Non-normative orientation to spoken English

19.S15: i do not (.) aim for a native speaker accent I simply wish <my 20.interlocutors $>$ could understand what i am saying and I could easily put 21. across what i would like to express (.) my English is that much sufficient= 
22. A: =i get it

23.S15: otherwise imitating a native speaker accent becomes a bit contrived= 24.A: =totally it loses its spontaneity a little more=

25.S15: =yes

26./.../

27.S15: it looks very ridiculous [from an objective view] <trying to speak with a 28. native speaker accent>

29.A: [moreover] it does not benefit <speakers> either so there is a settled 30. prejudice that if they can pretend <a native speaker accent> it sounds cool 31. and is prestigious and so on (.) from a social point of view to a degree, or 32. else $=$

33.S15: =no $\mathrm{i}$ think it never sounds COOL in our university in general almost all 34. lecturers studied abroad <in an English speaking country > but they all 35.speak like Turks i mean they do not attempt to mimic native speaker accents 36. because lecturer's purpose is to communicate something <knowledge to 37. students $>$ in other words $=$

38. A: = i see all right=

39.S15: =there <in academic settings $>$ it is not their aim to make a show off 40. <by speaking with a native English accent> a lecturer is a good one to the 41. extent that students can benefit from him/her

The above conversation occurred after a discussion with S15 about the difficulties he felt that he faced in speaking. It is understood from his remarks (II.19-21) that his prime goal is to interact with his interlocutors effectively by establishing mutual intelligibility. His explicit mention of 'native speaker accent' (I.15) as not being part of his goal for speaking reveals his belief that having native accent is, for him, not a condition to engage in successful communication. Furthermore, S15 seems to hold pejorative attitudes to native English accents' being imitated by people, with the belief that their speaking sounds strained and unnatural (II.23-24), and they thus look 'ridiculous' when attempting to pretend native English accents that pop out of nowhere. His strong reaction, (it never sounds COOL', II.33-37) to common-sense assumption that native accent is by definition 'cool and prestigious' is also an 
indication of his concern about communication over aesthetic features of Standard English, and a sign of feeling of ownership, which allows speakers to make their own way in using English, as is done by his lecturers (II.35-36). Lastly, reading between the lines in his resistance to imitation of native English accents, we can conclude that he is well aware of the role of English as a vehicle for academic studies in EMI courses. He therefore assesses lecturers' competence not based on their language use, but on the basis of their teaching skills and subject matter expertise (II.39-41).

As is the case with $\mathrm{S15}$, an overwhelming number of students preferred 'fluency', 'intelligibility', 'clarity', and 'ease of communication' over achieving native speaker competence (e.g. accent, pronunciation, pace, idioms, etc.). For instance, S1 replied "for me what matters foremost is to be fluent I would rather be fluent rather than know loads of [grammar rules] for example I would not mind even if my grammar is bad". The experience of being involved in an intercultural communication was also important in the formation of students' non-normative orientation to spoken English. S2, for example, told "I saw many people particularly in Spain who speak English without [standard native] accent (.) I even saw people who pronounced 'sometimes' as / 'z^n.taImz/ but you could understand it in the context of communication (.) For that reason neither native accent nor correctness matters (.) I think what matters there is whether you can manage to articulate things in a comprehensible way". S7, similarly, expressed that the main criterion for 'good English' should be based on intelligibility and communicative fluency rather than mimicking native speaker accents because, as clarified by him, "I do not think accent is something to be get rid of as long as interlocutors can comprehend what is uttered (.) There is nothing wrong with one's own accent anyone can carry over their first language traits in their accents but if they are able to speak fluently and pronounce words in an intelligible manner and interlocutors can follow what they say (.) I think there would be no nuisance". S13 also referred to her friends to make the point that linguistic errors in speaking make no harm on communication, stressing the fact that "I have Arab friends and they use English to communicate with us (.) I can easily understand their English although they make loads of grammatical mistakes". 
Another student, S20, referred to his previous experiences with English language learning, and mentioned how his spoken English practices were influenced by his English language teachers' beliefs and practices. He replied "I would like to speak without having to think about whether I should use past tense or present tense or which forms (.) I mean simple form progressive form or past form of verbs I have to use (.) I cannot help thinking about grammar when speaking". He further explained why he had to be so concerned about grammar rules while speaking, pointing to the reality that "they [teachers] never created opportunities for us to speak English but just taught us English grammar rules since grade four (.) It would have been better if we could have learned to use English communicatively but they kept teaching us present tense past perfect continuous tense and such like for years".

Another issue having emerged from the data in regards to the reason why many students are obsessed with grammatical correctness in their speech despite their desire to be fluent and successful communicators was associated with the notion of 'inferiority complex' among students. S6 argues that

"when you consider loosely, there is a kind of perception wannabe in Turkey now (.) As you mentioned we are in a constant effort to imitate their [the Americans \& British] languages, cultures, life styles (.) And in this regard it would not seem appropriate if we do not use their language as they do (.) We as the Turkish nation emulate anything and want everything to be as theirs (.) Surely this applies to our [English] language use as well".

Normative-expectations towards spoken English were less common among students. There were only a tiny number of them who were inclined to have a native accent, American accent in particular and to closely monitor their language use in respect of grammatical correctness. Paradoxically, there was a case in which S6 put that

"I would not mind your accent even if it is foreign-accented (.) What is important to me is being able to understand you that's enough for me (.) But as to me [my speaking] I think it has turned into a complex for me you see I say now that I will speak English some time in the future at least it should be proper (.) I do not ever mess with British accent at least I would like to speak like an American (.) I know it would not be exactly as theirs I wish it could be (.) I mean I could speak in a fluent way in that sense". 
As can be inferred, $\mathrm{S6}$ does not mind people's having their own accent, but for herself 'proper English' and 'fluent English' seem to be equal to that of Americans. In another exchange between a student and me, an instance of positive attitudes and a normative position towards native speakers and their accents in speaking was overtly observed.

Example 3: Native speaker oriented goals for speaking

42. S7: er <my> strongest skill (.) is speaking i suppose because $x x x$

43.A: though you mentioned a little while ago but what would you like your 44.speaking to be like. when you consider the future <use of language $>=$ 45.S7: =i'm not troubled with fluency <of my English> you see (.) i wish i had a 46.native speaker accent and such like @@@ you know

47. A: well let's suppose that you had a British accent or American accent what 48. would be the advantages <of having either of these accents> for you. 49.S7: i merely want <a native speaker accent> just because they sound cool 50.@@

51.A: @@ due to their being prestigious /.../

The above excerpt is a continuation of our discussion of S7's views on her academic English skills. As seen above, she identifies her strongest skill as speaking (I.42). I then asked her to elaborate more on her future goals as regards speaking. In answer to my question, she elucidates that she has no difficulty as to speaking fluently, but what she desires is to have one of 'native English accents'. She laughs a while after her own utterances (I.46) despite the lack of external stimuli. Her laughter might primarily serve to mitigate the meaning of the preceding utterance where she voices her wish for 'a native speaker accent'. To find out why she aspires to native accents, I asked her what advantages she would get if she had a native accent. As revealed later (I.49), her tendency to native accents is based on an ideological position, and originates in her belief that native accents 'sound cool'. The adjective 'cool' here is ideologically perceived with positive associations in relation to the notion of 'native speaker accents'. 
Besides targeting at dominant varieties of native speaker English, several students were seen to be considerably concerned with achieving their level of fluency and grammatical correctness. In a lengthy comment on her English, S18 defined her English and goal as follows: "I do not find my English perfect but consider it a good level of English I cannot speak with a NS accent my pronunciation may be considered good and of course I make mistakes while speaking but I can easily understand the articles in English write my thoughts (.) of course I wish I could speak without mistakes and more fluently". Here, it is understood from S18's statements that 'perfect English' is construed as free from mistakes and slower pace of non-native speech. For some students, their obsession with linguistic correctness in their speech was related to their worry about losing intelligibility in the case of committing mistakes while speaking English. To give an example, S6 stated that "I attempt to monitor my grammar usage you know (.) I mean you cannot express something that happened in the past with the future form of the verb". Moving to the subject of whose English sounds better, S10 made positive remarks about retaining a native accent, noting her opinion that "in my view having either British accent or American accent is favourable because they are the standards and easily comprehensible here there and anywhere". To make her point clear, she further added that "all in all any person let's say a Polish has heard American English the most but have not heard Turkish English at all (.) That's why it [American English] is a more familiar variety of English (.) Thus I conclude that everyone's speaking with a similar accent [native accent] will facilitate things [in communication] and increase intelligibility". It is clearly understood from the student's remarks that standard varieties of English, especially American and British English, is seen superior to any non-standard variety in terms of speaking because of people's being more familiar with the standard varieties.

\section{Discussion}

\subsection{Overall orientation towards English and English language use}

This study indicates that a great majority of students (56.4\%) described their English as closer to the dominant varieties of English, with $47,9 \%$ associating their 
English with the American English, supporting Guerra's (2005) findings that show Portuguese students' references to native varieties of English, particularly the American English in their descriptions of their English. Furthermore, with over onethird (40\%) accepting their English with its unique features, the results echo some previous findings (e.g. Guerra, 2005) while contradicting others (Kuteeva, 2014).

Despite students' tendency towards seeing their English as having the characteristics of a particular native standard, the results unearths the existence of hierarchies in which American English sits at the top followed by British English and other kinds of native English (e.g. Canadian English, Australian English) (see also Bayard et al. 2001; H. Lee, 2012). Moreover, it is noteworthy that most students in the questionnaire study showed an indication of ownership of English by acknowledging their English with the features of Turkish without referring to any native models of English. This finding is however at odds with previous findings, for example, that of Matsuda (2003) with Japanese learners of English.

As regards students' orientation to written English, it was discovered that many students $(59.8 \%)$ preferred to have writing competence of native speakers again in an hierarchical order, with American English (29.9\%) at the top followed by British English and other types of native English (8.5\%). Qualitative findings also substantiated students' normative approach to written English, and demonstrated how much they are concerned about linguistic correctness and getting closer to a near-native competence, providing support for previous research findings that users as well as learners of English feel like writing as native speakers do, particularly the Americans (e.g. Guerra, 2005; Karakaş, 2014; Timmis, 2002). It is inferred here based on the results that students maintained more positive attitudes towards native models when considering their future written English. However, there were also signs showing that a small group of students aspired to be competent writers of English, with the acceptance of mistakes that do not hinder effective written communication. A similar finding was previously reported with EMI lecturers who stressed the importance of being a competent writer, tolerating grammatical mistakes (Karakaş, 2014). 
When it comes to students' orientation to spoken English, a different picture emerged in that many students (45.3\%) adopted non-normative approach to spoken English, placing emphasis on the accomplishment of being a competent communicator who is capable of communicating in various English-speaking environments. Good English is hence conceptualized by these students not against a native speaker touchstone, but based on the criterion of speaking English effectively with their own varieties of English in a number of diverse contexts, finding support from the findings of previous studies (see also Erling, 2007; Guerra, 2005; Karakaş, 2014). Therefore, for these students, the ideal English speaker should not necessarily be a speaker from an inner circle country. Björkman's (2008) findings with engineering students are also in line with the finding that users of English considered effective communication more important than having high (native-like) proficiency. Against this finding, the students (51.8\%) who opted for native English varieties for their spoken English were slightly larger in number than the students who were competency-focused in their goals. Of the students who targeted a native speaker model for spoken English, those favouring the American speakers constituted the largest fraction (33.9\%), with British English as the second largest fraction (13.1\%). A similar ranking of native varieties for spoken English was made by non-language major EMI lecturers (Karakaş, 2014) and English learners (Guerra, 2005) in previous studies. As is understood, American English stands out from other varieties as the preferred variety of English when it comes to their own goals and expectations for spoken English.

Manifestations of positive attitudes and affinities to American English (e.g. Bayard et al., 2001; McKenzie, 2008) and British English (e.g. Dalton-Puffer, Kaltonboeck \& Smit, 1997; Ladegaard \& Sachdev, 2006), especially in terms of models of pronunciation have been well documented in previous research studies as well, particularly by in-service and prospective English language teachers and learners. However, there seems to be an increased awareness, particularly among English users, of the sociolinguistic realities of English alongside changing demographics of speakers of English around the world, as evidenced in this study with participants who accepted their variety of English as legitimate and formulated expectations and 
goals in accordance with this awareness, prioritizing effectiveness in global communication over adoption of a normative native-speaker model. Equally, scholars of Global Englishes have forcefully argued in favour of a radical change for the ideal model from targeting the monolingual native speaker to the successful user of English, who is described as the 'skilled English user' (Jenkins 2011, p. 931), 'effective communicator' (Björkman 2011, p.1) and 'intercultural speaker' (Baker 2011 , p. 4). Despite the differences in scholars' naming of the successful user, what they unanimously agree is that a successful user is anyone who is capable of modifying and adapting their language use in line with the communicative needs of their interlocutors and the interactional settings, with the application of appropriate pragmatic strategies in communication.

\subsection{Language ideologies and factors contributing to their formulation}

This research, as shown above, has investigated two distinct language ideologies, i.e. standard language ideology and English native speaker ideology, which guide most students' orientation to their perceived language use and their resolutions regarding their desired language use, particularly the use of productive English skills. This finding partly resonates with the findings of Pilkinton-Pihko (2010) that while engineering lecturers emphasized the significance of communication of course content to students, some were of the belief that the realization of such communication hinges on speaking English without grammatical errors. Such a belief reveals that they hold on to standard language ideology in which the notion of linguistic correctness is perceived to be closely tied up with the effective use of English. It also parallels Jenkins' (2014) finding that many international (non-native English speaker) students were concerned about 'linguistic correctness', particularly in writing, operating under the effect of standard language ideology. Similar findings usually emerged from previous empirical studies in the ELT profession with teachers and learners of English in which orientation to English was dominated by standard language ideology and native English language ideology (e.g. Liou, 2010; Jenkins, 2007). Yet, there are other studies done with non-native users (neither teachers nor learners) whose perceptions of English were independent from the impacts of 
standard and native English language ideologies, especially in relation to spoken English (e.g. Björkman, 2008; Ehrenreich, 2010; Kankaanranta \& Planken, 2010).

As intimated in students' excerpts, a number of factors (e.g. the affinity to native English models as a benchmark, investment in standard English norms, personal characteristics and interests, lecturers' normative expectations and practices of reducing students' marks, familiarity and having an EMI identity) have seemed to add to the formation and perseverance of the language ideologies among students in their perceptions and language use. Similar factors that feed language ideologies in speakers of English were reported in earlier studies with non-native language users in academia (e.g. Jenkins, 2014; H. Lee, 2012; Malallah, 2000) as well as business and service sectors (e.g. A. W. Lee, 2012; Rogerson-Revell, 2007) and language teachers and learners (e.g. Jenkins, 2007; Timmis, 2002). Nonetheless, a number of factors enabled students to perceive and use English free from the impacts of standard/native English ideologies. These include: involvement in intercultural communication practices of lecturers who modelled a non-normative language use, increasing awareness of implications of the global spread of English, a developing sense of ownership of English and revision of traditional goals and expectations with more communication-grounded goals (see also Björkman, 2008; Ehrenreich, 2010; Erling, 2007).

\section{Conclusion}

By investigating Turkish EMI students' orientation to English and English use, this study identified notable signs of awareness of the current face of English among many students, despite the perpetuation of language ideologies that drove students towards using English in a standard manner and choosing native speakers as the model speaker. In other words, it can be advanced that students' orientations, if considered as a pendulum, hovered between conformity to Standard English, especially in written English, and a focus on communicative effectiveness, particularly of spoken English. Factors that spread the seeds of language ideologies in most students' attitudes, perceptions, and practices were mainly related to longterm adverse effects of ELT experiences. It was also displayed that the students can 
be affected by wider agents (e.g. teachers, policy managers) and practices. Thus, it is essential to bear in mind their potential impacts on students' orientations to English. Other factors that encouraged the use of English in students' own ways were mainly based on experiential learning, e.g. making meaning from direct experiences (e.g. intercultural encounters, familiarity with other varieties and accents, etc.).

It is rather vital for researchers, not only from the fields of applied linguistics but also from the fields of higher education, to approach English language policies with a critical perspective in their research by questioning the taken-for-granted status of English. Especially, the role of the mentioned factors foregrounds the need for further research in such highly volatile linguistic contexts as higher education institutions. Moreover, content-focused lecturers alongside students are urged to take account of the findings and discussions presented in this paper, and accordingly revisit their pre-existing perceptions, and adjust their expectations and language practices to the current realities of English, keeping in mind that their primary purpose is to conduct their academic tasks through English rather than to display their English skills, often against native English benchmark. 


\section{Appendix A: The questions extracted from the questionnaire Personal Details}

1. Your age: 18-24 [ ] 25-32 [ ] 33+ [ ] 3. Your university:

2. Your gender: male [ ] female [ ] $\quad$ 4. Your department:

5. Would you be willing to participate in an interview to discuss your answers to the questions?

YES [ ] NO [ ]

If yes, please provide your contact information:

Email:

\section{Perceptions of English Ability}

What do you think about the English you use?

Please choose only one with a tick $(\checkmark)$

( ) It has its own characteristics with influence of the Turkish language

( ) British English (BrE) / closer to BrE

( ) American English (AmE) / closer to AmE

( ) Other:

\section{Goals for written academic English}

What is your goal in writing academic English? Please choose only one with a tick.

( ) to be a competent writer, that is, it's OK to make some grammatical mistakes as long as my writing is understood.

( ) to write like British speakers.

( ) to write like other native speakers of English (e.g. Australians, Canadians, etc.)

( ) to write like American speakers.

( ) other 


\section{Goals for spoken academic English}

What is your goal in speaking academic English? Please choose only one with a tick

( ) to be a competent speaker, that is, it's OK to have a Turkish accent and make some grammatical mistakes as long as I am understood

( ) to speak like British speakers.

( ) to speak like other native speakers (e.g. Australians, Canadians, etc.)

( ) to speak like American speakers.

( ) other 


\section{Appendix B: The interviewee profiles}

\begin{tabular}{|l|l|l|l|}
\hline Participant & Sex & University & Discipline \\
\hline Student 1 & Female & METU & International relations \\
\hline Student 2 & Male & METU & Mechanical Engineering \\
\hline Student 3 & Male & METU & History \\
\hline Student 4 & Male & METU & Mechanical Engineering \\
\hline Student 5 & Male & METU & Mechanical Engineering \\
\hline Student 6 & Female & METU & History \\
\hline Student 7 & Female & Bilkent & International relations \\
\hline Student 8 & Male & Bilkent & Mechanical Engineering \\
\hline Student 9 & Male & Bilkent & International Relations \\
\hline Student 10 & Male & Bilkent & Mechanical Engineering \\
\hline Student 11 & Female & Bilkent & History \\
\hline Student 12 & Male & Bogazici & Mechanical Engineering \\
\hline Student 13 & Female & Bilkent & History \\
\hline Student 14 & Female & Bogazici & International relations \\
\hline Student 15 & Male & Bogazici & International relations \\
\hline Student 16 & Male & Bogazici & International relations \\
\hline Student 17 & Female & Bogazici & Mechanical engineering \\
\hline Student 18 & Female & History \\
\hline Student 19 & Male & Mechanical engineering \\
\hline Student 20 & Male & Mechanical engineering \\
\hline
\end{tabular}




\section{Appendix C: Transcription conventions}

\begin{tabular}{l|l}
\hline Symbols & Explanations \\
\hline$()$. & Pause of about one second or less \\
\hline$(2)$ & Pause of about two seconds \\
\hline$\ldots$ & Untimed pause \\
\hline XXX & Unable to transcribe (unintelligible word or words) \\
\hline CAPS & Stressed word \\
\hline @ & Laughter (length indicated by a number of @) \\
\hline A & Ali (the researcher) \\
\hline L1, L2, L3 & EMI lecturers \\
\hline S1, S2, S3 & EMI students \\
\hline$[$ ] & Overlapping utterances \\
\hline$=$ & Latched utterances \\
\hline$?$ & Rising intonation \\
\hline . & Falling intonation \\
\hline uh-huh & used to indicate affirmation, agreement \\
\hline I../ & speech not included in the example \\
\hline$<>$ & my additional information to make meaning clear \\
\hline
\end{tabular}




\section{References}

Aguilar, Marta., \& Rosa Rodríguez. 2012. Lecturer and student perceptions on CLIL at a Spanish university. International Journal of Bilingual Education and Bilingualism, 15(2), 183-197. doi:10.1080/13670050.2011.615906

Baker, Will. 2011. From cultural awareness to intercultural awareness: Culture in ELT. ELT Journal, 66(1), 62-70. doi:10.1093/elt/ccr017

Bayard, Donn, Ann Weatherall, Cynthia Gallois, \& Jeffery F. Pittam. 2001. Pax Americana? Accent Attitudinal Evaluations in New Zealand, Australia and America. Journal of Sociolinguistics, 5, 22- 49.

Björkman, Beyza. 2008. "So where we are?" Spoken lingua franca English at a technical university in Sweden. English Today, 24(2), 35-41. doi:10.1017/S0266078408000187

Björkman, Beyza. 2011. The pragmatics of English as a lingua franca in the international university: Introduction. Journal of Pragmatics, 43(4), 923-925. doi:10.1016/j.pragma.2010.08.015

Brown, Kara. 2010. Teachers as Language-Policy Actors: Contending with the Erasure of Lesser-Used Languages in Schools. Anthropology \& Education Quarterly, 41(3), 298-314. doi:10.1111/j.1548-1492.2010.01089.x.298

Byun, Kiyong., Huijung Chu, Minjung Kim, Innwoo Park, Suhong Kim, \& Juyoung Jung. 2010. English-medium teaching in Korean higher education: policy debates and reality. Higher Education, 62, 431-449. doi:10.1007/s10734-010-9397-4

Dalton-Puffer, Christiane, Gunther Kaltenboek \& Ute Smit. 1997. Learner attitudes and L2 pronunciation in Austria. World English. 16(1), 115-128. 
Dearden, Julie. 2014. English as a medium of instruction-a growing global phenomenon: phase 1 Interim report (pp. 1-8). Oxford: British Council.

Doerr, Neriko Musha. 2009. Investigating "Native Speaker Effects": Toward a new Model of Analyzing "Native Speaker" Ideologies. In Neriko Musha Doerr (ed.) The Native Speaker Concept: Ethnographic Investigations of Native Speaker Effects (pp. 15-46). Berlin: Mouton de Gruyter.

Ehrenreich, Susanne. 2010. English as a lingua franca in multinational corporationsExploring business communities of practice. In Anna Mauranen \& Elina Ranta (eds.) English as a Lingua Franca: Studies and Findings. (pp. 126-151). Newcastle upon Tyne: Cambridge Scholars Publishing.

Erling, Elizabeth. 2007. Local identities, global connections: Affinities to English among students at the Freie Universität Berlin. World Englishes, 26(2), 111-130.

Guerra, Luís Sergío Pinto. 2005. Teaching and Learning English as an International Language in Portugal: Policy, Practice, Perceptions. Warwick: University of Warwick PhD Thesis.

Jenkins, Jennifer. 2007. English as a lingua franca: Attitudes and identity. Oxford: Oxford University Press.

Jenkins, Jenkins. 2011. Accommodating (to) ELF in the international university. Journal of Pragmatics, 43(4), 926-936. doi:10.1016/j.pragma.2010.05.011

Jenkins, Jennifer. 2014. English as a Lingua Franca in the international university. The politics of academic English language policy. London: Routledge.

Kankaanranta, Anne \& Leena Louhiala-Salminen. 2010. "English?-Oh, it's just work!": A study of BELF users' perceptions. English for Specific Purposes, 29(3), 204209. 
Karakaş, Ali. 2014. Lecturers' Perceptions of Their English Abilities and Language Use in English-Medium Universities. International Journal on New Trends in Education and Their Implications, 5(2), 114-125.

Kuteeva, Maria. 2014. The parallel language use of Swedish and English: the question of "nativeness" in university policies and practices. Journal of Multilingual and Multicultural Development, 35(4), 332-344. doi:10.1080/01434632.2013.874432

Ladegaard, Hans \& Itesh Sachdev., 2006. "I like the Americans... but I certainly don't aim for an American accent": language attitudes, vitality and foreign language learning in Denmark. Journal Multilingual and Multicultural Development, 27(2), 91-108.

Lee, Ann Whan-Hsin. 2012. Language Ideology of English: Its Relation with Linguistic Ownership. Taipei: National Taiwan Normal University Master Thesis.

Lee, Hsiu-Ya. 2012. An investigation of Taiwanese university students' attitudes towards ELF. Southampton: University of Southampton PhD Thesis.

Liou, Yi-Shin. 2010. Who wants EIL? Attitudes towards English as an international language: comparative study of college teachers and students in the greater Taipei area. College English: Issues and Trends, 3, 135-157.

Lippi-Green, Rosina. 2012. English with an Accent: Language, Ideology, and Discrimination (2nd edn.) London: Routledge.

Ljosland, Ragnhild. 2011. English as an Academic Lingua Franca: Language policies and multilingual practices in a Norwegian university. Journal of Pragmatics, 43(4), 991-1004. doi:10.1016/j.pragma.2010.08.007

Ljosland, Ragnhild. 2010. Teaching Through English: Monolingual Policy Meets Multilingual Practice, Hermes, 45, 99-113. 
Makihara, Miki, \& Bambi B. Schieffelin. 2007. Cultural Processes and Linguistic Mediations: Pacific Explorations. In Miki Makihara and Bambi B. Schieffelin (eds.) Consequences of Contact: Language Ideologies and Sociocultural Transformations in Pacific Societies. (pp. 3-29). Oxford: Oxford University Press.

Malallah, Seham. 2000. English in an Arabic environment: Current attitudes to English among Kuwait university students. International Journal of Bilingual Education and Bilingualism, 3(1), 19-43.

Matsuda, Aya. 2003. The ownership of English in Japanese secondary schools. World Englishes, 22(4), 483-496.

Mauranen, Anna. 2003. The Corpus of English as Lingua Franca. TESOL Quarterly, $37(3), 513-527$.

McKenzie, Robert M. 2008. Social factors and non-native attitudes towards varieties of spoken English: a Japanese case study. International Journal of Applied Linguistics, 18(1), 63-88.

Milroy, James \& Lesley Milroy. 2012. Authority in Language: Investigating Standard English (4th edn.) New York: Routledge.

Milroy, James. 2001. Language ideologies and the consequences of standardization. Journal of Sociolinguistics, 5(4), 530-555. doi:10.1111/1467-9481.00163

OECD (Organisation for Economic Co-operation and Development). 2011. Education at a Glance 2011. OECD Indicators. Retrieved from http://www.oecd.org/education/skills-beyond-school/48631582.pdf accessed $3 / 12 / 2014$

OECD (Organisation for Economic Co-operation and Development). 2013. Turkey in International Migration Outlook 2013. OECD Publishing. Retrieved from http://dx.doi.org/10.1787/migr outlook-2013-43-en accessed 3/12/2014 
Pennycook, Alastair. 1994. The Cultural Politics of English as an International Language. New York: Longman.

Pilkinton-Pihko, Diane. 2010. English as a lingua franca lecturers' self-perceptions of their language use. In Anna Mauranen and Niina Hynninen (eds.) English as a Lingua Franca [Special Issue] Helsinki English Studies, 6, 58-74.

Preisler, Bent. 2009. Complementary languages: The national language and English as working languages in European universities. Angles on the English-Speaking World, 9, 10-28.

Rogerson-Revell, Pamela. 2007. Using English for International Business: A European case study. English for Specific Purposes, 26(1), 103-120.

Saarinen, Taina \& Tarja Nikula. 2013. Implicit Policy, Invisible Language: Policies and Practices of International Degree Programs in Finnish Higher Education. In Aintzane Doiz, David Lasagabaster, \& Juan Manuel Sierra (Eds.). English-medium instruction at universities: Global Challenges. (pp. 131-150). Bristol: Multilingual Matters.

Shohamy, Elana. 2006. Language policy: Hidden agendas and new approaches. London: Routledge.

Spolsky, Bernard. 2004. Language policy. Cambridge: Cambridge University Press.

Timmis, Ivor 2002. Native-speaker norms and International English : a classroom view. ELT Journal, 56, 240-249.

Turner, Yvonne, \& Sue Robson. 2008. Internationalizing the university. London: Continuum. 
Wächter, Bern \& Friedhelm Maiworm. 2008. English-Language-Taught Degree Programmes in European Higher Education. The Picture in 2007. Bonn: Lemmens Medien.

\begin{abstract}
Ali Karakaş studied English Language Teaching (ELT) for his BA at Uludag University and took MA courses at Hacettepe University, Turkey. Being sponsored by Mehmet Akif Ersoy University, where he is also employed as a research assistant in the ELT department, he is currently pursuing his $\mathrm{PhD}$ at Southampton University. His research interests chiefly include English as a Lingua Franca, Language Policies, Language Attitudes and Ideologies, and Language Teacher Education.
\end{abstract}

